\title{
NOTE
}

\section{Laboratory observations on displacement speed of the white shrimp Penaeus vannamei (Crustacea: Decapoda)}

\author{
Rafael Solis-Ibarra, Sergio Rendon-Rodriguez \\ Estacion 'Mazatlan', Instituto de Ciencias del Mar y Limnología, Universidad Nacional Autónoma de México, PO Box 811, Mazatlan, \\ Sinaloa, 82000 Mexico
}

\begin{abstract}
Laboratory observations were carried out on displacement speed of the penaeid shrimp Penaeus vannamej Boone, 1931 in the water column along a $10 \mathrm{~m}$ perimeter tank. The experimental group consisted of 52 adult shrimp: 27 females ( 60 to $85 \mathrm{~g}$ ) and 25 males ( 45 to $60 \mathrm{~g}$ ) under feeding stress. The estimated average displacement speed for females and males was 34.47 and $32.05 \mathrm{~cm} \mathrm{~s}^{-1}$ respectively.
\end{abstract}

KEY WORDS: Penaeus vannamei - Displacement - Speed . Penaeidae $\cdot$ Shrimps

Shrimp, which are negatively buoyant, have to swim actively to maintain their position in the water column. Their displacement is carried out with 3 types of appendages: pereiopods, pleopods and uropods. Pereiopods (4 to 5) are also used to walk. Hill (1985) reported a walking speed of 4 to $6 \mathrm{~cm} \mathrm{~s}^{-1}$ for Penaeus seculentus Haswell. Pleopods are used for swimming; some penaeids are active swimmers and migrating adults can travel tens of nautical miles during the autumn season (Kim 1973, Ruello 1975, Glaister et al. 1987). When alarmed, a penaeid will characteristically give several rapid, powerful strokes with the uropods while flexing the abdomen, driving the shrimp swiftly backwards.

Material and methods. The experimental group consisted of 52 adult shrimp (27 females and 25 males) of Penaeus vannamei from the brood stock of a shrimp hatchery. Weights ranged from 60 to $85 \mathrm{~g}$ for females and 45 to $60 \mathrm{~g}$ for males. Specimens were kept under controlled conditions [temperature $28^{\circ} \mathrm{C}$, salinity $35 \%$ and $11 \mathrm{~h}$ of light exposure $[02: 00$ to $13: 00 \mathrm{~h})]$ in a $10 \mathrm{~m}$ perimeter and $0.5 \mathrm{~m}$ deep, cylindrical tank. Observations on displacement speed were made $1.5 \mathrm{~h}$ after feeding, when shrimp began to swim again in search of food. Time was registered with a chronometer $( \pm 0.05 \mathrm{~s}$ ). Data were registered only for shrimp that completed a circuit of the perimeter of the experimental tank and primarily included only movements of males. Females were found not to move as much as males, and when they did, they often changed direction without completing a circuit of the tank. Among 136 observations only $18.38 \%$ corresponded to female movements.

Results and discussion. Registered swimming times for males and females ranged from 20 to 39.9 s (Table 1), with an average value of $30.8 \mathrm{~s}( \pm 4.53 \mathrm{SD}$ ) and an average speed of $33.2 \mathrm{~cm} \mathrm{~s}^{-1}( \pm 5.21)$ was obtained. Ko et al. (1970) report that adults of Penaeus japonicus Bate (120 to $240 \mathrm{~mm}$ total length) swim at a speed of $54 \mathrm{~cm} \mathrm{~s}^{-1}$, while Dall et al. (1990) found that adults of $P$. merguiensis De Man swim at 20 to $30 \mathrm{~cm} \mathrm{~s}^{-1}$. Data related to migration speeds of shrimps are estimated on the basis of recapture of tagged shrimps. Chang Cheng (1984) determined a migration speed of $9.7 \mathrm{~cm} \mathrm{~s}^{-1}$ for $P$. chinensis (Osbeck, 1765), while Montgomery (1981) suggested 4 to $8 \mathrm{~cm} \mathrm{~s}^{-1}$ for $P$. plebejus

Table 1. Penaeus vannmaei. Frequency distribution of time taken by adult shrimp to cover $10 \mathrm{~m}$ of tank perimeter

\begin{tabular}{|cccc|}
\hline Time (s) & Females & Males & Total \\
\hline $20-21.9$ & 1 & 2 & 3 \\
$22-23.9$ & 4 & 3 & 7 \\
$24-25.9$ & 3 & 9 & 12 \\
$26-27.9$ & 2 & 14 & 16 \\
$28-29.9$ & 4 & 17 & 21 \\
$30-31.9$ & 3 & 15 & 18 \\
$32-33.9$ & 4 & 19 & 23 \\
$34-35.9$ & 2 & 14 & 16 \\
$36-37.9$ & 2 & 11 & 13 \\
$38-39.9$ & 0 & 7 & 7 \\
Total & 25 & 111 & 136 \\
\hline
\end{tabular}


Hess, 1865 and Rufilson (1983) found that juveniles of $P$. aztecus Ives and $P$. duorarum Burkenroad sank at a speed of around $8 \mathrm{~cm} \mathrm{~s}^{-1}$ when drifting in a tidal current. These values are estimated based on distance between sites of release and recapture of tagged shrimps. They represent a distance covered over several days and differ from our observations in the sense that they most likely include inactive periods.

In some species (Penaeus merguiensis and P. plebejus), size and sex do not appear to affect migration speeds (Frusher 1985, Glaister et al. 1987). However, in the case of $P$. vannamei, different displacement speeds were found. Averages were $32.05 \mathrm{~cm} \mathrm{~s}^{-1}$ for males and $34.47 \mathrm{~cm} \mathrm{~s}^{-1}$ for females $\left(t=2.093>t_{0.25,132}=2.04\right)$, the difference perhaps being associated with size.

Acknowledgements. We thank Mr Carlos Reyes Garzon for all facilities provided in 'Cultivos Morales' shrimp hatchery at Sn. Blas, Nayarit, Mexico. Thanks are also due to Michel Hendrickx and Albert Van der Heiden for their comments and useful suggestions.

\section{LITERATURE CITED}

Chang Cheng, Y (1984). The prawn (Penaeus orientalis Kishinouye) in Pohai Sea and their fishery. In: Gulland, J. A., Rothschild, B. J. (eds.) Penaeid shrimps - their

This note was submitted to the editor biology and management. Fishing News Books, Farnham, p. $49-60$

Dall, W., Hill, B. J., Rothlisberg, P. C., Sharples, D. J (1990). The biology of the Penaeidae. Advances in marine biology, Vol. 2 $\overrightarrow{7}$. Academic Press, New York

Frusher, S. D. (1985). Tagging of Penaeus merguiensis in the Gulf of Papua, Papua New Guinea. In: Rothilsberg, P. C.. Hill, B. J., Staples, D. J. (eds.) Second Australian national prawn seminar. NPS2, Cleveland, Australia, p. 65-70

Glaister, J. P., Lau, T., McDonall, V. C. (1987). Growth and migration of tagged eastern Australian king prawns, Penaeus plebejus Hess. Aust. J. mar. Freshwat. Res. 38: $225-241$

Hill, B. J. (1985). Effect of temperature on duration of emergence, speed of movement and catchability of the prawn Penaeus esculentus. In: Rothlisberg, P. C., Hill, B. J., Staples, D. J. (eds.) Second Australian national prawn seminar. NPS2, Cleveland, Australia, p. 77-83

Kim, B. (1973). Studies on the distribution and migration of Korean shrimp, Penaeus orientalis Kishiouye, in the Yellow Sea. Bull. Fish. Dev. Agency, Busan ll: 7-23

Ko, K. S., Suzuki, M., Kondo., Y (1970). An elementary study on behaviour of common shrimp to moving net. Bull. Jap. Soc. Sci. Fish. 36: 556-562

Montgomery, S. S. (1981). Tagging studies on juvenile eastern king prawns reveal record migration. Aust. Fish. 40(9): 13

Ruello, N. V. (1975). Geographical distribution, growth and breeding migration of the eastern Australian king prawn Penaeus plebejus. Aust. J. mar. Freshwat. Res. 26: 343-354

Rufilson, R. A. (1983). Behtavioural aspects of juvenile penaeid shrimp Penaeus aztecus and Penaeus duorarum during tidal transport. Contr mar Sci. 26: 55-64

Manuscript first received: June 14, 1993

Revised version accepted: September 22, 1993 